\title{
FIRST RECORDS OF TWO REMARKABLE COLEOPTERA SPECIES CUCUJUS CINNABERINUS AND METOECUS PARADOXUS (COLEOPTERA: CUCUJIDAE, RHIPIPHORIDAE) FROM THE REPUBLIC OF KARELIA (RUSSIA)
}

\author{
Alexei V. Polevoi ${ }^{1}$, Andrei E. Humala ${ }^{1}$, Elena V. Kulebyakina ${ }^{2}$, Nadezhda N. Kutenkova ${ }^{3}$ \\ ${ }^{1}$ Forest Research Institute of Karelian Research Centre of RAS, Russia \\ e-mail: alexei.polevoi@krc.karelia.ru,humala@krc.karelia.ru \\ ${ }^{2}$ National Park «Vodlozersky», Russia \\ e-mail:vodloz_no@mail.ru \\ ${ }^{3}$ State Nature Reserve «Kivach», Russia \\ e-mail:kutenkova.nn@mail.ru \\ Received: 20.03.2018

\begin{abstract}
Viable populations of two remarkable Coleoptera species - Cucujus cinnaberinus (Cucujidae) and Metoecus paradoxus (Rhipiphoridae) are reported for the first time from the Republic of Karelia (Russia). Cucujus cinnaberinus is a threatened species in northern Europe while Metoecus paradoxus is a widespread Palaearctic species actively dispersing northwards. Both species were found in the nature protected areas by the local staff. This evidences the importance of such territories for preserving and monitoring the populations of rare and poorly known species.
\end{abstract}

Key words: Coleoptera, Cucujidae, Karelia, Rhipiphoridae, rare species

\section{Introduction}

The Coleoptera fauna of Karelia is relatively well studied, largely due to the works of Finnish researchers who, since the end of the nineteenth century, published extensive lists, mainly based on material collected in the southern regions of the republic (Poppius, 1899; Palmén, 1946). Some more recent studies consider particular taxonomic (Titova, 1959; Makarov \& Shorokhov, 1986; Uzenbaev et al., 1986) and ecological (Jakovlev et al., 1986; Mozolevskaya et al., 1991) groups or summarise observations from certain protected areas (Rutanen \& Kashevarov, 1997). Others provide the Coleoptera species lists for limited geographical regions as a part of more general entomological surveys (Yakovlev et al., 2000; Humala \& Polevoi, 2009; Jakovlev et al., 2014). The latest additions to the Karelian fauna include some rather rare saproxylic species (Siitonen et al., 1996; Martikainen et al., 2014; Polevoi et al., 2017) and species dispersing northwards or introduced by people (Humala \& Polevoi, 2015). In this paper, we give new data on two Coleoptera species Cucujus cinnaberinus (Scopoli, 1763) and Metoecus paradoxus (Linnaeus, 1761) representing an important addition to the Karelian fauna.

\section{Material and Methods}

This communication is based on authors' observations in the State Reserve «Kivach» and the National Park «Vodlozersky», Karelia, Russia (Fig. 1). Specimens of M. paradoxus are stored in the col- lections of Forest Research Institute (Petrozavodsk) and State Reserve «Kivach». The male of C. cinnaberinus was released after taking photographs.

\section{Results}

Family Cucujidae

Cucujus cinnaberinus (Scopoli, 1763)

Material. Russia, Karelia, National Park «Vodlozersky», $62.15^{\circ} \mathrm{N}, 36.80^{\circ} \mathrm{E}, 10 \mathrm{~km} \mathrm{SW}$ of Kuganavolok, 10.06.2017. One male specimen was observed, at the base of a large aspen tree (Fig. 2 ). The beetle was actively moving on the trunk surface from the base to a height of about $1 \mathrm{~m}$. The site (Vaccinium myrtillus L. type spruce-dominated forest, about 180 years old, with an admixture of pine, birch and aspen) is located along a dirt road. Some large aspens (trunk diameter 50-60 cm) were felled during roadworks. The remaining alive aspens have a diameter of $35-45 \mathrm{~cm}$.

Distribution. Found throughout most of Europe but largely absent in the south and west (Horák et al., 2010; Nieto et al., 2010). In the middle of XX century several specimens of $C$. cinnaberinus were found in the areas of the Leningrad province, neighbouring to Karelia - Gumbaritsy (Palmén, 1946). The record by J. Siitonen with coauthors (1996) from Kuganavolok refers to elytra found under the bark of aspen (P. Martikainen, pers. comm.). A new observation from Karelia is hence the first one, confirming the presence of a viable population in the republic. 


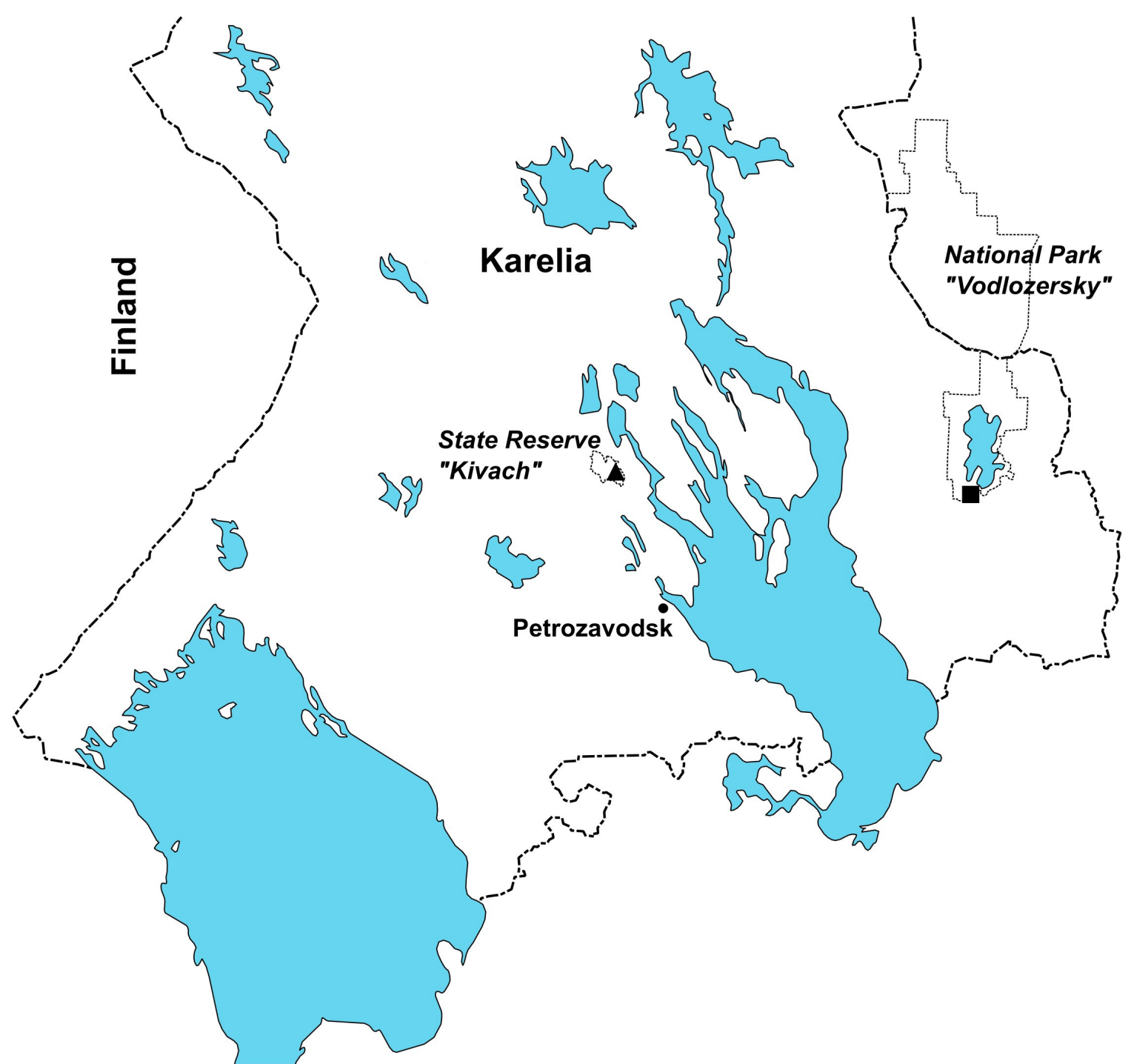

Fig. 1. Collecting localities in Karelia: - -Cucujus cinnaberinus; $\mathbf{\Delta}$-Metoecus paradoxus.

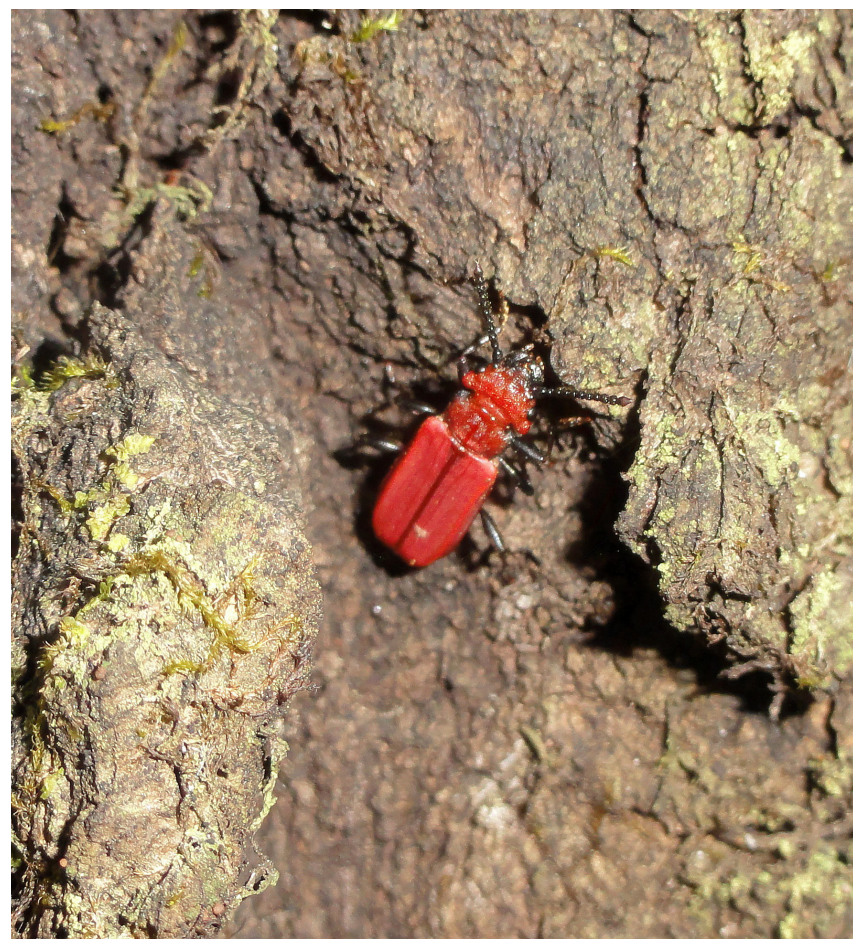

Fig. 2. Cucujus cinnaberinus, male. Photo by E.V. Kulebyakina.

Biology. Saproxylic species, living under the bark of a variety of broad-leaved trees and rarely on conifers (Nieto et al., 2010). In Finland it prefers fallen aspen logs with loose bark (J. Siitonen, pers. comm.). Larvae and adults are predators of saproxylic invertebrates (Mazzei et al., 2011). Horák et al. (2010) discussed habitat preferences of this species in the Czech Republic.

Remarks. The species is categorised as «Near Threatened» in the IUCN Red List (Nieto et al., 2010). It is expanding in central-eastern Europe and on some colder Mediterranean mountains, but declining in the surrounding areas (Horák et al., 2010; Mazzei et al., 2011; Šag et al., 2016). The status of the populations in European Russia is not clear due to scarce records. Classified as Critically Endangered in Karelia (Ivanter \& Kuznetsov, 2007), and Rare (category 3 ) in Voronezh province (Negrobov, 2011). Threat factors include fragmentation and increasing isolation of beetle populations due to forestry, removal, and destruction of large trees. 
Family Rhipiphoridae

Metoecus paradoxus (Linnaeus, 1761)

Material. Russia, Karelia, State Reserve «Kivach», $62.27^{\circ} \mathrm{N}, 33.98^{\circ} \mathrm{E}, 12.09-16.10 .2017$. Seven males and two females were collected inside the laboratory building, located at the edge of the main settlement of the nature reserve, between herb-rich meadow and mixed forest.

Distribution. Palaearctic, from Great Britain to Japan (Heitmans \& Peeters, 1996). In Russia south and central European parts, northwards to Leningrad province (Iablokoff-Khnzorian, 1976).

Biology. Heitmans \& Peeters (1996) summarised the complex life history of $M$. paradoxus which is an obligatory parasite, developing in fullgrown larvae of social wasps of the genera Vespula Thomson, 1869 and Dolichovespula Rohwer, 1916. According to Van Oystaeyen et al. (2015), emerged beetles mimic the methylalkane profile of their main host $V$. vulgaris (Linnaeus, 1758) to avoid detection. Specimens collected by the authors (Fig. 3) evidently penetrated into the building from a wasp nest located in the neighbourhood. Some females still bore the remnants of pupal shell on the body.

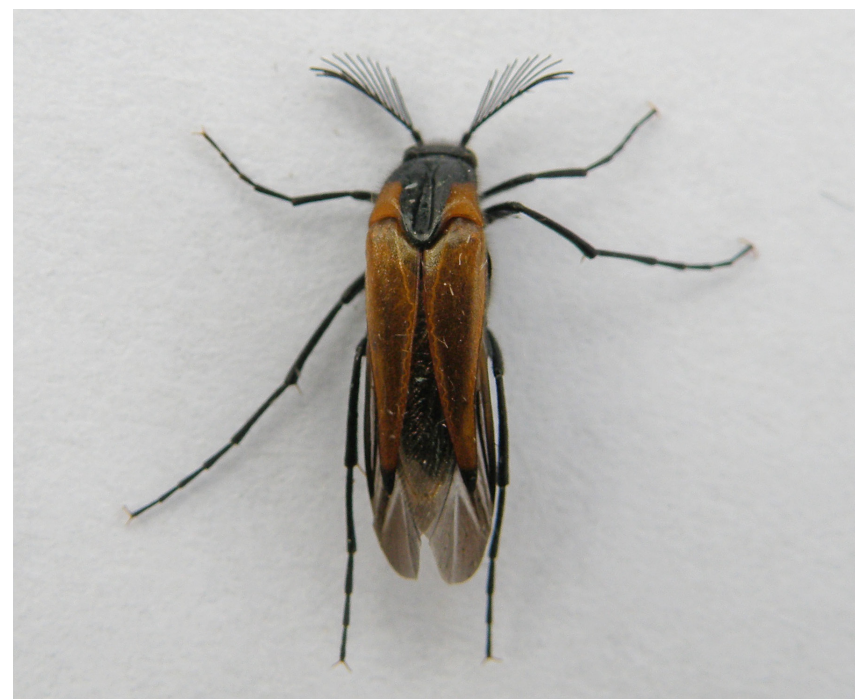

Fig. 3. Metoecus paradoxus, male. Photo by N.N. Kutenkova.
Remarks. Though there is a chance that $M$. paradoxus might have been overlooked due to its cryptic way of life, we believe that this species is a real newcomer to Karelia. For example, in the State Reserve «Kivach», it has not been recorded during continuous annual light trapping since 1991 (Kutenkova, 1997, 2006, 2016), though is known to be attracted to light (Heitmans \& Peeters, 1996). In Norway, Sweden and Finland $M$. paradoxus has considerably advanced northwards during recent years (Fig. 4). The new record from Karelia indicates a similar trend in north-western Russia, which has been already observed in other insect species (Humala \& Polevoi, 2015).

\section{Conclusions}

The network of nature protection areas in Karelia provides an excellent base for researchers in the field of biology. Strictly protected territories usually are the best choice for long-term ecological and faunistic studies, and most of the recent additions to the insect fauna of Karelia are the result of such studies. Both species considered in this paper were found in protected areas and, what is more important, were detected by the local staff, partly by not professional entomologists. This once more evidences the importance of such territories for preserving and monitoring the populations of rare and poorly known species.

\section{Acknowledgements}

Authors sincerely acknowledge valuable comments of anonymous reviewers on the manuscript. The study was carried out under state order to the Karelian Research Centre of the Russian Academy of Sciences (Forest Research Institute KRC RAS). The work of E.V. Kulebyakina and N.N. Kutenkova was implemented under state assignment of Ministry of Nature Resources of the Russian Federation (051-00023-17-00 and 051-03-2018-048).
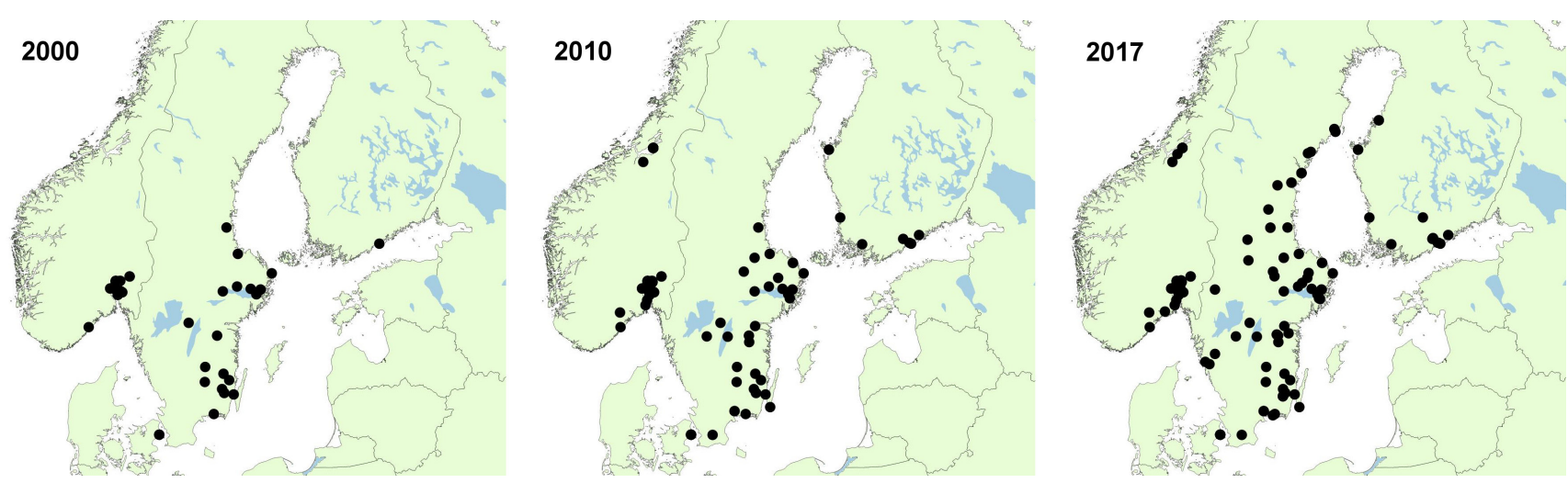

Fig. 4. Occurrences of Metoecus paradoxus in Norway, Sweden and Finland up to 2000, 2010 and 2017. (Data from www. gbif.org: GBIF occurrence download https://doi.org/10.15468/dl.bukjzr). 


\section{References}

Heitmans W.R.B., Peeters T.M.J. 1996. Metoecus paradoxus in The Netherlands (Coleoptera: Rhipiphoridae). Entomologische Berichten 56(7): 109-117.

Humala A.E., Polevoi A.V. 2009. On the insects fauna of South-East Karelia. Transactions of the Karelian Research Centre of the Russian Academy of Sciences 9(4): 53-75. [In Russian]

Humala A.E., Polevoi A.V. 2015. Records of rare and noteworthy insect species (Insecta) in the Republic of Karelia. Transactions of the Karelian Research Centre of the Russian Academy of Sciences 6: 19-46. [In Russian]. DOI: $10.17076 /$ bg 30

Horák J., Vávrová E., Chobot K. 2010. Habitat preferences influencing populations, distribution and conservation of the endangered saproxylic beetle Cucujus cinnaberinus (Coleoptera: Cucujidae) at the landscape level. European Journal of Entomology 107(1): 81-88. DOI: 10.14411/eje.2010.011

Iablokoff-Khnzorian S.M. 1976. Beetles of the family Rhipiphoridae (Coleoptera) of the fauna of the USSR. II. Entomologicheskoe obozrenie 55(2): 410-424. [In Russian]

Ivanter E.V., Kuznetsov O.L. (Eds.). 2007. Red Data Book of Republic Karelia. Petrozavodsk: Karelia. 368 p. [In Russian]

Jakovlev J.B., Shorokhov V.V., Gorbunova V.H. 1986. Materials to the fauna of xylophagous beetles of Karelia. In: J.B. Jakovlev, S.D. Uzenbaev (Eds.): Fauna and ecology of arthropods of Karelia. Petrozavodsk: Karelian Branch of USSR AS. P. 40-59. [In Russian]

Jakovlev J., Polevoi A., Humala A. 2014. Insect fauna of Zaonezhye Peninsula and adjacent islands. In: T. Lindholm, J. Jakovlev, A. Kravchenko (Eds.): Biogeography, landscapes, ecosystems and species of Zaonezhye Peninsula, in Lake Onega, Russian Karelia. Reports of the Finnish Environment Institute. Helsinki: Finnish Environment Institute. P. 257-338.

Kutenkova N.N. 1997. Species composition and dynamics of butterflies (Heterocera, Macrolepidoptera) in different biotopes of Kivach Nature Reserve in 1991-1993. In: A.V. Kravchenko (Ed.): Flora and fauna of the nature protected territories of Karelia. Issue 1. Petrozavodsk: Karelian Research Centre of RAS. P. 73-82. [In Russian]

Kutenkova N.N. 2006. Results of the Moth Monitoring Scheme in Nature Reserve «Kivach» in 1995-2005. Proceedings of the State Nature Reserve «Kivach» 3: 19-47. [In Russian]

Kutenkova N.N. 2016. Results of the Moth Monitoring Scheme from «Kivach» Nature Reserve in 2006-2015. Proceedings of the State Nature Reserve "Kivach» 7: 25-55. [In Russian]

Makarov A.M., Shorokhov V.V. 1986. On the fauna and ecology of weevil beetles (Coleoptera, Curculionidae) of the State Reserve «Kivach». In: J.B. Jakovlev, S.D. Uzenbaev (Eds.): Fauna and ecology of arthropods of Karelia. Petrozavodsk: Karelian Branch of USSR AS. P. 60-74. [In Russian]
Martikainen P., Humala A., Polevoi A. 2014. Ischnodes sibiricus Tsherepanov, 1966 (Coleoptera, Elateridae) found in Russian Karelia. Sahlbergia 20(2): 32-34.

Mazzei A., Bonacci T., Contarini E., Zetto T., Brandmayr P. 2011. Rediscovering the 'umbrella species' candidate Cucujus cinnaberinus (Scopoli, 1763) in Southern Italy (Coleoptera Cucujidae), and notes on bionomy. Italian Journal of Zoology 78(2): 264-270. DOI: 10.1080/11250003.2010.485210

Mozolevskaya E.G., Galasjeva T.V., Chemeris M.V. 1991. Species composition and spatial distribution peculiarities of xylophagous insects in «Kivach» Nature Reserve. In: J.B. Jakovlev, E.G. Mozolevskaya (Eds.): Entomological studies in «Kivach» Nature Reserve. Petrozavodsk: Karelian Research Centre of USSR AS. P. 66-74. [In Russian]

Negrobov O.P. (Ed.). 2011. Red Data Book of the Voronezh Region. Vol. 2: Animals. Voronezh: MODEK. 424 p. [In Russian]

Nieto A., Mannerkoski I., Putchkov A., Tykarski P., Mason F., Dodelin B., Horák J., Tezcan S. 2010. Cucujus cinnaberinus. In: The IUCN Red List of Threatened Species 2010: e.T5935A11921415. Available from: http:// www.iucnredlist.org/details/5935/0. DOI: 10.2305/ IUCN.UK.2010-1.RLTS.T5935A11921415.en

Palmén E. 1946. Kenntnis der Käfer fauna im westlichen Swir-Gebiet (Sowiet-Karelien). Acta Societas pro Fauna et Flora Fennica 65(3): 1-195.

Polevoi A.V., Nikitsky N.B., Mandelshtam M.Ju., Humala A.E. 2017. On the insect fauna of dead wood at the early stage of decay. Izvestia Sankt-Peterburgskoj Lesotehniceskoj Akademii 220: 33-45. DOI: 10.21266/2079-4304.2017.220.33-45 [In Russian]

Poppius B. 1899. Förteckning öfver Ryska Karelens Coleoptera. Acta Societas pro Fauna et Flora Fennica 18(1): 1-125.

Rutanen I., Kashevarov B. 1997. Coleoptera of the Nature Reserve Friendship with adjacent primeval forests. In: R. Heikkilä, T. Lindholm, M. Heikkilä (Eds.): Ecosystems, fauna and flora of the Finnish-Russian Nature Reserve Friendship. Helsinki: Finnish Environment Institute. P. 257-294.

Siitonen J., Martikainen P., Kaila L., Mannerkoski I., Rassi P., Rutanen I. 1996. New faunistic records of saproxylic Coleoptera, Diptera, Heteroptera, Homoptera and Lepidoptera from the Republic of Karelia, Russia. Entomologica Fennica 7(2): 69-76.

Šag M., Turić N., Vignjević G., Lauš B., Temunović M. 2016. The first record of the rare and threatened saproxylic Coleoptera, Cucujus cinnaberinus (Scopoli, 1763), Rhysodes sulcatus (Fabricius, 1787) and Omoglymmius germari (Ganglbauer, 1891) in Kopački rit Nature Park. Natura Croatica 25(2): 249-258. DOI: 10.20302/ NC.2016.25.20

Titova E.V. 1959. Bark beetles of coniferous growth on forest felling in Karelia. Transactions of Karelian Branch of USSR AS 16: 110-126. [In Russian]

Uzenbaev S.D., Bobrovskikh T.K., Shorokhov V.V. 1986. Species composition and distribution of ground beetles 
(Coleoptera, Carabidae) in south Karelia. In: J.B. Jakovlev, S.D. Uzenbaev (Eds.): Fauna and ecology of arthropods of Karelia. Petrozavodsk: Karelian Branch of USSR AS. P. 74-83. [In Russian]

Van Oystaeyen A., van Zweden J.S., Huyghe H., Drijfhout F., Bonckaert W., Wenseleers T. 2015. Chemical Strategies of the Beetle Metoecus paradoxus, Social Parasite of the Wasp Vespula vulgaris. Journal of Chemical Ecology 41(12): 1137-1147. DOI: 10.1007/s10886-015-0652-0
Yakovlev E., Scherbakov A., Polevoi A., Humala A. 2000. Insect fauna of Paanajärvi National Park and proposed Kalevala National Park with particular emphasis on Saproxylic Coleoptera, Diptera and Hymenoptera. In: R. Heikkilä, M. Heikkilä, A. Polevoi, E. Yakovlev (Eds.): Biodiversity of old-growth forests and its conservation in the northwestern Russia. Oulu: North Ostrobothnia Regional Environmental Centre. P. 103-157.

\title{
ДВА ПРИМЕЧАТЕЛЬНЫХ ВИДА ЖЕСТКОКРЫЛЫХ CUCUJUS CINNABERINUS И METOECUS PARADOXUS (COLEOPTERA: CUCUJIDAE, RHIPIPHORIDAE) ВПЕРВЫЕ НАЙДЕНЫ В КАРЕЛИИ
}

\author{
А. В. Полевой ${ }^{1}$, А. Э. Хумала ${ }^{1}$, Е. В. Кулебякина ${ }^{2}$, Н. Н. Кутенкова ${ }^{3}$ \\ ${ }^{1}$ Институт леса Карельского научного ичентра РАН, Россия \\ e-mail:alexei.polevoi@krc.karelia.ru,humala@krc.karelia.ru \\ ${ }^{2}$ Национальный парк «Водлозерский», Россия \\ e-mail:vodloz_no@mail.ru \\ ${ }^{3}$ Государственный заповедник «Кивач», Россия \\ e-mail:kutenkova.nn@mail.ru
}

\begin{abstract}
На территории Республики Карелия (Россия) впервые обнаружены жизнеспособные популяции двух примечательных видов жесткокрылых - Cucujus cinnaberinus (Cucujidae) и Metoecus paradoxus (Rhipiphoridae). Cucujus cinnaberinus является угрожаемым видом в Северной Европе, а Metoecus paradoxus - широко распространенный палеарктический вид, активно продвигающийся в северном направлении. Оба вида были обнаружены штатными сотрудниками на особо охраняемых природных территориях. Новые находки подчеркивают важность заповедников и национальных парков для сохранения и мониторинга популяций редких и слабо изученных видов насекомых.
\end{abstract}

Ключевые слова: Coleoptera, Cucujidae, Rhipiphoridae, Карелия, редкие виды 